\title{
EVENTS KIBS ON THE BUSINESS SERVICES MARKET - A NETNOGRAPHY ANALYSIS
}

\author{
KRZYSZTOF BORODAKO, ${ }^{1}$ JADWIGA BERBEKA, ${ }^{2}$ MICHAŁ RUDNICKI ${ }^{3}$ \\ ${ }^{1}$ Cracow University of Economics, POLAND \\ e-mail:borodako@uek.krakow.pl \\ ${ }^{2}$ Cracow University of Economics, POLAND \\ e-mail: jadwiga.berbeka@uek.krakow.pl \\ ${ }^{3}$ Cracow University of Economics, POLAND \\ e-mail: michal.rudnicki@uek.krakow.pl
}

RECEIVED
ACCEPTED
JEL
CLASSIFICATION

KEYWORDS

ABSTRACT
10 August 2017

18 December 2017

L84, L86, M31, D83

business services, KIBS, netnography, Internet, search engine marketing, competition

Two important roles of KIBS, knowledge sources for innovation and the recognisability of Internet offers for these kinds of services, are rarely amalgamated. To fill this gap, both research streams were integrated to investigate the level of interest in specific types of KIBS services in the online environment. To achieve this goal, a netnography analysis has been used. As a result of the analysis of the KIBS offer on the Internet, the following groups of KIBS were identified: leaders, advanced, promising and professional niche. The level of competition among firms in KIBS industry was additionally measured by introducing a KSD (Keyword Search engine optimisation Difficulty) parameter.

\section{Introduction}

Over the last 25 years the importance of the business services market has increased exponentially, which has been recognised in both business practice and numerous scientific studies. One of the most significant changes has been the increasing importance of knowledge-based factors in service processes and the development of information communications technology, especially on the Internet (Whiting, Hansen, Sen, 2017). A company's online presence 
has become an objective necessity and is an important feature of its business, constituting a significant determinant of market success. However, in order for KIBS to support the activities of other companies, their offer must be visible online, which has become the main source of information and basic communication tool. This is particularly true of Events KIBS (E-KIBS) - their knowledge and innovations determine the success of events organised by clients and reports from such events build the client's image in the eyes of potential customers and competitors.

Nevertheless, the roles of KIBS as knowledge sources for innovation and the recognisability of their offer on the Internet are rarely connected. To fill this gap, in this article both research streams were integrated to investigate the level of interest in specific types of KIBS services in the online environment. To achieve this goal, a netnographic analysis has been used, which has gained popularity in recent years as a method of research in various fields of science (Seyfi, Soydaş, 2017).

\section{KIBS and their role on the business services market}

Companies are offering more novel customised solutions and the role of knowledge-intensive business services (KIBS) is increasing in significance (Muller, Zenker, 2001). KIBS firms provide services based on professional knowledge, making a strategic contribution to their clients' business activities (Miozzo, Grimshaw, 2005). As a result, companies must incorporate such services into their offers. According to Doloreux and Shearmur (2010, p. 611), "KIBS refers to establishments that are characterised by high knowledge intensity and that offer predominantly non-routine services to their clients." KIBS combine various types of highly specialised knowledge in order to develop (either innovative or non-innovative) problem-specific solutions (Muller, Zenker, 2001).

Based on research concerning KIBS (Miles et al., 1995; Muller, Doloreux, 2009) and Borodako, Berbeka, Rudnicki $(2014 ; 2016)$, it has been shown that event services have identical characteristics to those of other types of services provided by KIBS. Hence the following KIBS classification was incorporated into the research:

- Market services:

- market research,

- advertisement,

- social science research.

- Company services:

- legal services,

- accountancy,

- work agency/recruitment agency services,

- business, management consultancy services and public relations.

- Technical services:

- architectural services,

- IT services,

- engineering services.

- Event services:

- fair \& congress services,

- incentive travel agency services,

- catering,

- audio-video-lighting (AVL) services. 
Muller and Doloreux (2009) acknowledge highly specialised business services as a unique subsector of services because the services provided by KIBS are complicated, unstructured and characterised by their adaptation to the unique needs of the client (Bettencourt, Ostrom, Brown, Roundtree, 2002, p. 101). The same traits describe event services which support and create innovation and "customisation" - unique solutions linked to "tacit knowledge". That knowledge remains an aspect of the human factor whose invention is a critical element determining the success of the whole event. Interaction with clients and firms generates new knowledge (Muller, Zenker, 2001) that may result in the development of service innovations. That is why the KIBS offer must be clearly visible on the Internet by bringing together companies interested in close cooperation.

\section{The role of the Internet in business operations conducted by sepvice providers}

The Internet opened a new procurement channel for companies, which allows them to reach customers all over the world. Its development influences the way marketing communication is conducted. Although the focus has been centred on companies that act solely on the web, the Internet may substantially affect companies that sell their services through traditional channels.

The literature highlights the crucial role of social media (SM) (Boyd, 2010). SM allows the company and customer to communicate with each other, but also allows customers to communicate with each other about the company and create an electronic word of mouth (Hennig-Thurau, Gwinner, Walsh, Gremler, 2004). For companies, well-managed social media provides a potential tool to gain insight about customer attitudes, as well as an opportunity to spread commercial information using the customer as an information channel (Vilnai-Yavetz, 2016).

In the literature it is claimed that with the rapid advancement in ICT the economy is moving towards a more information-based economy (Kumar, Kumari, Ruan, Garza-Reyes, Akkaranggoon, 2014). A study by Rauyruen and Miller (2007) suggests that B2B service providers need to understand the nature and circumstances of their customers. One form of customer behaviour is searching for information about a potential client or partner on the Internet.

Internet search engine marketing (SEM) is a form of company activity on the Internet. This form of marketing is acknowledged as being minimally invasiveness because of the lack of intrusive tools (usually pop-up advertisements), and because it is in line with a customer's search for specific content.

The presented study focuses on organic (natural) search engine results, leaving aside the issue of paid advertisements appearing as sponsored links. The reason for this approach was our research objective, related to the analysis of business services promoted and researched on the Internet. The level of difficulty in obtaining a specific website among the initial results provided by search engine is one form of competition on the Internet. This issue is related to the term page optimisation, i.e. optimal positioning in search results (called Search Engine Optimisation - SEO).

The literature contains statements suggesting that relevant phrases or keywords significantly affect positioning in search results. The selection of these keywords is particularly important when positioning (Ostrowski, 2012). Keyword analysis makes it possible to identify new concepts not yet used by competitors or corresponding to new consumer trends (Frontczak, 2006, p. 39). 


\section{Methodology}

The research based on interviews conducted with selected KIBS companies some years ago confirmed that one of the two key ways of acquiring new business clients (on the B2B market) was the Internet - positioning and advertising on the Internet. Based on this conclusion, we implemented a relatively new method: netnography. The name suggests its essence; it is a combination of Internet and ethnography. The main aim of using this method is an analysis of online communities (Kozinets, 2010), but it is also used in marketing research related to consumer behaviour, needs and trends (Belk, 2017). The standard procedure for this method is based on data available directly from computer-mediated communications by members of the online community. In this study, a modified version of the method was applied, adjusted to research on the B2B market where relations differ from those of final consumers. The data available from online tools was implemented by companies in their Internet marketing activities, mainly Google Trends, Google Adwords and KeyWords Finder. All these tools allow authors to analyse the activities of companies that want to advertise successfully on the Internet.

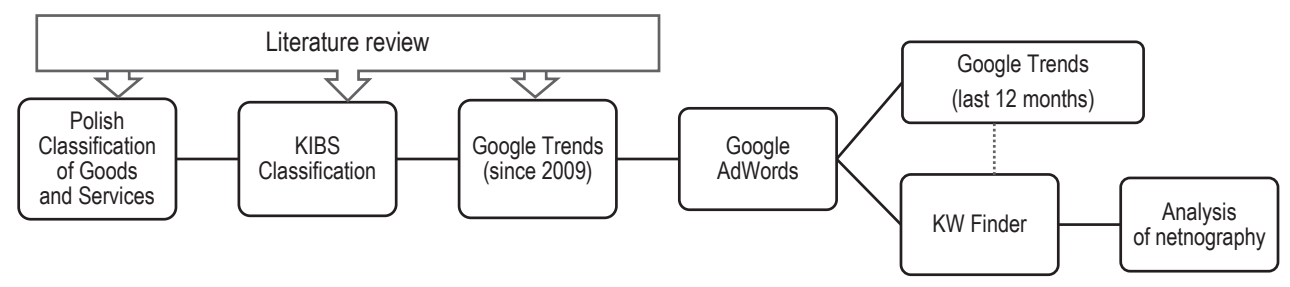

Figure 1. Conceptual process for data selection with use of Google Trends

Source: own elaboration.

The procedure was divided into two steps. These steps were preceded by an analysis of the Polish Classification of Goods and Services, where KIBS firms were identified according to the applied KIBS classification. The literature review was conducted throughout preparation of the selection. The first step was collecting the data from 2009 to 2017 for all types of KIBS with Google Trends. By using Google Adwords, it was possible to find the keywords that are more frequently used by Internet users when they are looking for particular type of KIBS. The second step involved using Google Trends to analyse data from the last 12 months with a parallel analysis of data by KW Finder. These two data sets were compared to determine whether the changes were similar. Finally, only KW Finder tool was used for further study because it offers more detailed data and provides absolute data on inquiries for the analysis. The conceptual process of selecting the data is presented in Figure 1.

\section{KIBS in the Internet environment - resullts of the empirical research}

On the basis of the most frequently used keywords selected, we conducted an analysis of the popularity of KIBS firms in the Internet environment. The first approach to the study was to calculate the average number of search queries for selected English keywords in the Google search engine. Each type of KIBS was compared and the difference in interest within groups of KIBS was investigated. In the first approach, three dominant types of services were indicated: advertisement (over 15 thousand), architectural services (almost 12 thousand) and 
legal services (almost 11 thousand). These three types of KIBS can be called "leaders" and have the highest scores. Three others groups of KIBS can also be distinguished: "advanced" - these include: accounting services, work agencies and AVL services - these services (in other words keywords associated with these services) are entered into a search engine over 30 thousand times a month. The third group is consists of five types of KIBS (the biggest group with the highest spread/range of number of search queries). They can be called "promising" KIBS, because their potential to develop in the Internet environment should significantly improve in the near future. This group includes: market research, IT services (with over 20 thousand results), social science research, catering, and fair and congress services. The last group of services identified in the research were KIBS called "professional niche", which describes both the structure of this group and the specific features of these services. This group includes: management services and public relations, engineering services and incentive travel agency services. This represents a mixture of all three groups of KIBS, because the selection included: Company KIBS, Technical KIBS and Event KIBS (Figure 2).

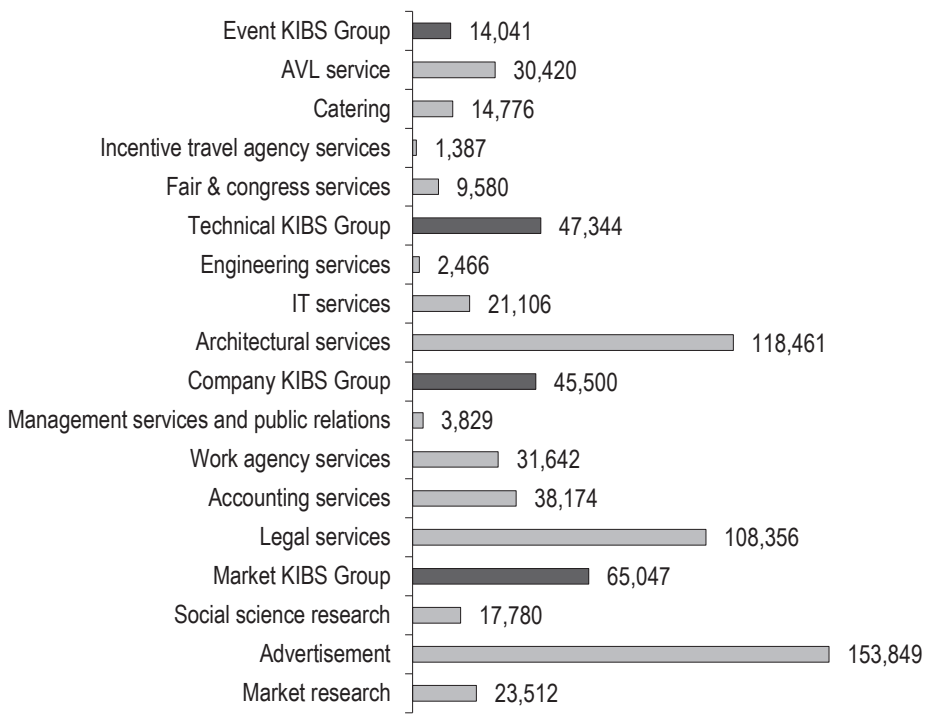

Figure 2. Average number of keyword queries connected with KIBS on the Internet (in English)

Source: own elaboration on the basis of the research.

The second approach in the netnography analysis was an attempt to identify and measure the competition between companies within each type of service and, on a smaller scope, among other KIBS. In this analysis, the authors applied a measurement used in Internet marketing (in particular in search engine optimisation) called "keyword SEO difficulty" - KSD), which represents the level of competition for keywords used to position the webpages of companies (mostly supported by professional marketing agencies). The higher this measurement is, the greater the competition in search engine results positioning in the case of these keywords. In other words, if a company wants to be positioned high in search engine results, for example on the first page or at the top of the first page, it must make an extra effort to achieve it. 
The structure of the KIBS is similar as in the previous analysis; there were groups of KIBS and particular types of KIBS. Competition in the KIBS industry is noticeably very strong. The three services with the highest level of KSD were identified - architecture, legal and market services (scores between 64-58, qualified in the system as "hard" to be successful). The next two types of KIBS with a high level of KSD were fair and congress services and advertisement (both with scores of 53 , at the top of these spread values). All other types of KIBS were described as "possible" areas for achieving success, and only AVL services were described as "easy enough". No KIBS were classified in the ranges described as "just go", "valuable to go", "easy". This analysis confirms that competition in KIBS services in the Internet environment is very intense. KSD levels and the range of recommendations for marketers are presented in Figure 3.

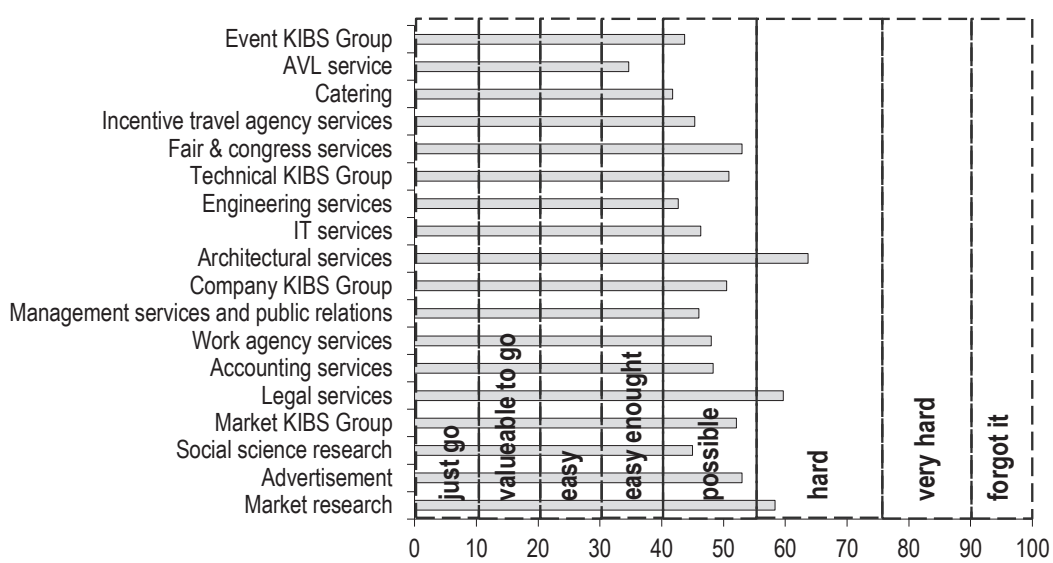

Figure 3. Level of keyword search engine optimisation difficulty (KSD) for terms connected with KIBS on the Internet (in English)

Source: own elaboration on the basis of the research.

Trend functions in the number of Internet searches for specific groups of KIBS services (see Table 1) were estimated for a 12-month period (December 2016 - November 2017).

Table 1. Linear trend line equation and $\mathrm{R}^{2}$ value for the number of keyword searches for groups of KIBS services on the Internet from December 2016 - November 2017 (keywords in English, searched in English on the Internet)

\begin{tabular}{l|c|c}
\hline \multicolumn{1}{c|}{ KIBS group } & Trend line equation & $R^{2}$ value \\
\hline Market & $y=1246.2 x+57433$ & $R^{2}=0.5486$ \\
Company & $y=652.56 x+41231$ & $R^{2}=0.2233$ \\
Technical & $y=253.38 x+42088$ & $R^{2}=0.0385$ \\
Event & $y=289.67 x+12073$ & $R^{2}=0.3303$ \\
\hline
\end{tabular}

Source: own elaboration on the basis of the research. 
The estimated trend functions had different matching ratios: acceptable $\left(R^{2}=0.5486\right)$ for Market services, a little weaker for Company and Event services, and, in the case of Technical services, very weak.

The interpretation of parameters of trend functions describing changes in the number of searches for particular groups of services on the Internet shows that in the initial period (December 2016), the most Internet searches referred to keywords connected with Market services (over $57 \mathrm{k}$ times in a month). The other two groups (Company and Technical) obtained a starting point that was lower by more or less $1 / 4$, receiving over $41 \mathrm{k}$ searches. The group of services described as Event was the subject of Internet searches with much lower frequency at just over $12 \mathrm{k}$ times.

The analysis of parameter "a" proves that the dynamics of changes in interest in particular types of KIBS services expressed by Internet searches during the analysed period was the highest for Market services, in which interest increased by nearly 1,250 searches monthly. In the case of Business services, that increase was by 650 searches monthly. Growing interest in Event services led to an increase in the number of searches by 290 monthly and in Technical services by over 253. This illustrates the potential of Event services.

\section{Conclusions}

The results of the netnography analysis reveal that KIBS are a significant part of the services market; demand for them is intense and has continued to grow in 2017. As a group, KIBS play different roles on the market, as measured by the number of Internet searches.

Within Event KIBS, client interest measured by the number of Internet queries is the highest in the case of AVL services and the lowest for Incentive Travel Agency services. The number of queries for Event KIBS services in comparison with the other three KIBS groups is lower. This suggests that services within this group are in the introduction/growth phase of their life cycle.

The difficulty of positioning Event KIBS is the highest in case of Fair \& congress services, which underscores the fierce competition between companies offering these services.

The dynamic increase in the numbers of searches for Event KIBS on the Internet in 2017 was not as high as for Market and Company services, but it was higher than for Engineering services.

\section{Acknowledgement}

Project financed under National Science Centre (Poland) grant number 2016/23/B/HS4/03011.

\section{Referencess}

Belk, RW. (2017). Qualitative Research in Advertising. Journal of Advertising, 46 (1), 36-47.

Bettencourt, L., Ostrom, A., Brown, S., Roundtree, R. (2002). Client co-production in knowledge-intensive business services. California Management Review, 44, 100-128.

Borodako, K., Berbeka, J., Rudnicki, M. (2014). Professional services in business tourism. In Polish, Krakow: Foundation of the Cracow University of Economics.

Borodako, K., Berbeka, J., Rudnicki, M. (2016). KIBS as a factor in meetings industry competitiveness creation in Krakow, Poland. In: J.J.M. Ferreira, M.L. Raposo, C.I. Fernandes, M. Dejardin (eds.), Knowledge Intensive Business Services and Regional Competitiveness (pp. 211-235). New York: Routledge.

Boyd, D. (2010). Social Network Sites as Networked Publics: Affordances, Dynamics, and Implications. In: Z. Papacharissi (ed.), Networked Self: Identity, Community, and Culture on Social Network Sites (pp. 39-58). 
Doloreux, D., Shearmur, R. (2010). Exploring and comparing innovation patterns across different knowledge intensive business services. Economics of Innovation and New Technology, 19 (7), 605-625.

Ellsworth, J.H., Ellsworth, M.V. (1997). Marketing on the Internet. New York, NY: Wiley.

Hennig-Thurau, T., Gwinner, K.P., Walsh, G., Gremler, D.D. (2004). Electronic word-of-mouth via consumer-opinion platforms: What motivates consumers to articulate themselves on the Internet? Journal of Interactive Marketing, 1 (18), 38-52.

Kozinets, R.V. (2010) Netnography: Doing Ethnographic Research Online. London: Sage.

Kumar, V., Kumari, A., Ruan, X., Garza-Reyes, J.A., Akkaranggoon, S. (2014). Investigating Key Antecedents of Customer Satisfaction in B2B information Service Firms. Conference Paper in: IFIP Advances in Information and Communication Technology, November 2014. DOI: 10.1007/978-3-662-45526-5_30.

Miles, I., Kastrinos, N., Flanagan, K., Bilderbeek, R., Den Hertog, P., Huntink, W., Bouman, M. (1995). Knowledge-intensive business services. Users, carriers and sources of innovation. Luxembourg: EIMS.

Miozzo, M., Grimshaw, D. (2005). Modularity and innovation in knowledge-intensive business services: IT outsourcing in Germany and the UK. Research Policy, 34, 1419-1439.

Muller, E., Doloreux, D. (2009). What we should know about knowledge-intensive business services. Technology in Society, 31 (1), 64-72.

Muller, E., Zenker, A. (2001). Business services as actors of knowledge transformation: The role of KIBS in regional and national innovation systems. Research Policy, 30 (9), 1501-1516.

Ostrowski, J. (2012). Dobrze dobrane słowa. Marketing w Praktyce, 3, 46-47.

Rauyruen, P., Miller, K.E. (2007). Relationship quality as a predictor of B2B customer loyalty. Journal of Business Research, 60 (1), 21-31.

Seyfi, M., Soydaş, A.U. (2017). Instagram Stories from the Perspective of Narrative Transportation Theory. The Turkish Online Journal of Design, Art and Communication, 7 (1), 47-60.

Vilnai-Yavetz, I. , Levina, O., Medzhybovska, N. (2016). Assessing Social Media E-Visibility: A Framework To Compare Goods Vs. Service Firms. In: Developments in Marketing Science: Proceedings of the Academy of Marketing Science, Rediscovering the Essentiality of Marketing (pp. 197-201).

Whiting, R.H., Hansen, P., Sen, A. (2017). A tool for measuring SMEs' reputation, engagement and goodwill. Journal of Intellectual Capital, 18 (1), 170-188.

Zyguła, M. (2010). Synergia linków i pozycjonowania. Marketing w Praktyce, 11, 32-34.

Cite this anticle aS: Borodako, K., Berbeka, J., Rudnicki, M. (2018). Events KIBS on the business services market - a netnography analysis. European Journal of Service Management, 3 (27/1), 7-14. DOI: 10.18276/ejsm.2018.27/1-01. 